\title{
Influence of Industrial Attachment on the Competence of Instructors and Students in Enabling Creative Innovations for Industrialisation in Kenya
}

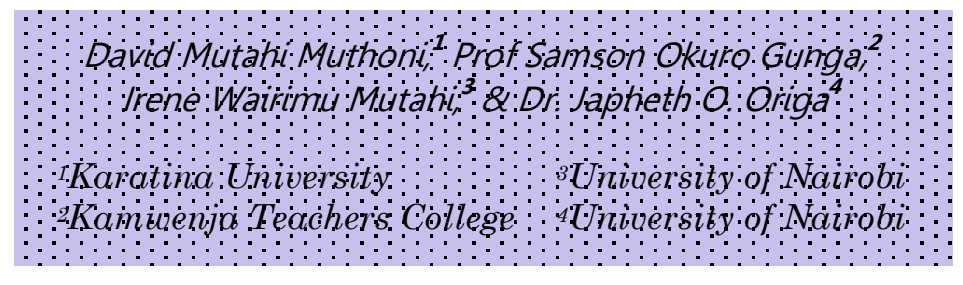

\section{Abstract}

Industrial Attachment was a key imperative for instructors who train in technical disciplines. Student attachment had been practised for several decades. However, teaching staffs' industrial attachment (TSIA) was a novel idea in developing countries. TSIA could improve the learning environment for competence-based training and assessment (CBTA). Akin to in-service training, TSIA would boost the abilities of staffs in determining relevant content materials; provide linkages with industries on-the-job training and use of appropriate pedagogical strategies for graduates' competitive-edge in the world of work. Competent human capital development in the current technological trends would encourage creative innovations for rapid industrialization desired in 
Kenya. Shortage of creative innovations among technical and vocational graduates which was associated with instructional challenges had persisted. However, reviewed literature focused on research and publicaions, instructors' in-service training (INSET), further education, social and industrial partners' participation in developing curriculum among other strategies for improving students' performance in curriculum based examinations. Although TSIA could encourage creative innovation and catalyze rapid industrialization, it had not been fully exploited. Yet, graduates' lack of creative innovations had persisted. The purpose of this study was to establish the influence of industrial attachment on instructors' and students' competence in creative innovations for improved industrial output. The objective of the study was to determine the influence of TSIA activities on the quality of students' industrial output in Kenya. The study found that TSIA played an important role in establishing a link with socio-industrial partners, relating teaching and learning processes to the latest development in the industries, providing opportunities for working with most current technology, machinery, equipment, tools and systems, contributing to product and industrial 
processes through creative innovations, involvement of industrial staff in students' competence development, reducing cost of recruitment and hence improving industrial savings. The study concluded that if collaborative industrial attachment between instructors and students was practised, the result was improved students' competence in creative innovations leading to globally competitive industrial output. The study recommended involvement of industrial and social partners in standardized assessment of collaborative supervised industrial attachment for students and academic staff.

\section{Introduction}

Like other developing countries, Kenya endeavoured to provide flexible technical, industrial, vocational and entrepreneurship training (TIVET) aimed at training skilled manpower, prepare the youth for self-employment, generate new knowledge through research and creative innovations and stimulate industrial takeoff (Brunnet, 2006; GoK, 2005; Muthoni, 2012). Besides other running costs, Kenya spent scarce foreign exchange to import expensive equipments 
for TIVET (Kerre, 2010; Muthaa, 2009) while TIVET was about five (5) times more expensive than general education (Kerre, 2010).Yet, the investment was not commensurate with graduate output. The studies by Brunnet (2006); GoK (2005); Kerre (2010); Muthoni (2012) and Ngware (2000) did not investigate the influence of TSIA as a catalyst for creative innovations for the desired rapid industrialization in Kenya.

On-going on-the-job and off-the-job academic staff training and development can motivate staff and students to produce creative innovations. The rapid changes in technology, the use of information communication technology (ICT) for diagnostic evaluation of automated systems in maintenance, repair and operations (MRO) and labour market conditions call for an elaborate teaching staffs industrial attachment (TSIA) for implementation of competence-based training and assessment, CBTA (Duger, 2011; GoK, 2010; Kuppe \& Loring, 2006 and Yan, 2011). Combined with supervised industrial attachment (SIA), TSIA will guarantee the development of creative innovation. Industrial attachment anchored on a standardized curriculum for both academic staff and their students could spur Kenya to a knowledge-based economy, provide 
employable skills and create opportunities for selfemployment. Creative innovations will encourage job creation through increased productivity in agricultural activities, reduce food insecurity, provide adequate medical care, clean water, efficient transport and communication networks, optimize industrial processes and lead to creative industrial products for socio-economic development as enshrined in Vision 2030 (GoK, 2005; ILO, 2010; Kerre, 2010; NCST, 2012). Despite the need for qualified personnel, students' technical and vocational competence in creative innovations is low (Kerre, 2010; King and Palmer, 2010). Low graduate competence in creative innovations has been associated with instructional challenges which include poor training strategies, instructors' lack of industrial experience and inadequate training equipments and facilities as well as inappropriate training and development of TIVET educators (GoK, 2009; Ngerechi, 2003; Yan, 2011). Dominative instructional strategies which were prevalent in TIVET institutions helped student acquire facts, theories and principles for examination purposes but they did not develop the necessary skills and competencies needed for creative innovations (Khakala, 2009; Kerre, 2011). TIVET instructors require retraining through in- 
service training (INSET) which emphasises industrial attachment and incorporates supervised industrial attachment of students for optimum results. However, the current scenario is such that collaboration between TSIA and supervised students industrial attachment is not fully exploited.

\section{Problem}

Low competence in creative innovations among TIVET students is a concern of various stakeholders because graduates' industrial output is not commensurate with the investments. The low competence in creative innovations can be attributed to instructional challenges because little attention is given to instructors' development and training. TIVET instructors were found to lack industrial experience; $90 \%$ of those working in public TIVET systems need upgrading. The purpose of this study was to establish the influence of industrial attachment on instructors' and students' competence in creative innovations for industrial output. The objective of the study was to determine the influence of TSIA activities on the quality of students' industrial output in Kenya. 


\section{Literature}

The global view of TIVET instructions in developed countries such as Britain, Germany and Japan among others was anchored on the advent of digital simulation for learning in engineering, creative designing, architect, and actuarial science (Zachary, 2009); robot teachers in Japan (Gatonye \& Mathenge, 2009); mobile phone learning in Korea (Nyantino, 2009). Instructional activities could help students to effectively use the physical tools for enjoyment, nurture social interaction, creative and innovative learning (Kerre, 2010; Muthoni, 2012; Zachary, 2009). Students in Singapore used teambased technology for simulation of real world projects. The technology used in Singapore included IDEALab and mobile devices for innovations and designing for enterprise applications (Maithya \& Ndebu, 2011; Yan, 211). To overcome the challenge of overuse of digital simulation without hands-on experience, the Germany dual system of education provided practical experiences to students in TIVET by division of time between working in industries and school instructions through industry -based projects (Kerre, 2010; Kuppe, \& Loring, 2006). Similarly, Singapore TIVET instruction emphasized hands-on (manipulative skills), minds-on 
(intellectual skills) and hearts-on (soft-skills) philosophy. The emphasis was work-flow of industrial practices that provided experiential understanding of the real workplace and develop relevant industry portfolios (ILO, 2010 and Yan, 2011). Collaboration between teaching staff and students' industrial attachment could deal with complexities of real world problems of deadlines and resource constraints (Kuppe \& Loring, 2006). European Union member countries such as the UK, Switzerland, Republic of Ireland and Sweden recognized the role of industries in students' situational training and collaborative learning in the provision of competence-based training and assessment, CBTA (Brunnet, 2006; Duger, 2011 and $\mathrm{Wu}, 2011)$. In particular, the European Union member countries recognized the need to involve skilled academic staff to work in partnership with industries to provide mentoring and coaching of apprentices (ILO, 2010). However, collaborative learning between teaching staff and their students had not been given due attention.

The Kenyan desire to develop TIVET graduates with $21^{\text {st }}$ century creative innovations for rapid industrialization depended on her ability to tap from foreign exchange potential in renewable 
energy and green technology along with skills gap in new and emerging technology (Kerre, 2011 and Kerre, 2010). Similarly, developed economies such as the USA, European Union member countries recognized the role of competence-based training and assessment (CBTA) to tap from renewable energy and green technology global market potential. The leading green technology economies included Japan, Germany and China (Kerre, 2010). Germany, aimed at using renewable energy as impetus for exports, economic growth and a means of reducing youth unemployment by offering 170,000 jobs (ILO, 2010; Kuppe \&Loring, 2006 and Brunet, 2006). China was also expected to set up clean coal and wind power plants and planned to triple her wind power generation by 2010 so as to become the largest wind power producer by 2020 . California in the US planned to reduce carbon gas emissions by $25 \%$ by 2020 and cut the emission by $80 \%$ by 2050 (Wu, 2011 and Kerre, 2010). However, involvement of social and industrial partners in enabling collaboration between teaching staff and students in the $21^{\text {st }}$ century instruction in TIVET disciplines to enable them make use of the new and emerging technologies in developing countries like Kenya had not been fully exploited (Kerre, 2010, 2011 and $\mathrm{Wu}, 2011)$. 
Modelling TIVET of Kenya and Africa countries on East and South Eastern Asian countries (Chinese, Taipei, Japan, Hong Kong, and Singapore) was aimed at encouraging and supporting knowledge-based economies, skills development and to respond to modern and emerging technological advancement, enormous energy need for industrialization by 2030 and modernization in a competitive world (Kerre, 2011). Singapore competed globally and favourably ahead of emerging industrial tigers like Korea, China and India (Agrawal, 2011) because of her prowess in encouraging and supporting knowledge-based economies, industry-related skills development that respond to modern and emerging technological advancement (Kerre, 2011; Yan, 2011 and Mar, 2011). Although Singapore had superior TIVET instructions, Indian and Chinese home-based industrial production which used hand-held tools where learners produced for the market were a notch higher. Particularly, Chinese TIVET instructions were rich in $21^{\text {st }}$ century employability skills development based on use of practical and occupational agricultural skills training and innovations. Consequently, Chinese industries produced cement, synthetic fibres, plastics, paper and paper-board; bicycles, motor vehicles and 
television receivers, and pharmaceuticals (Maclean, 2007). The above scenario whereby home-based industries are integrated with education and where learners produce for the market suggested the need for involvement of students in industries. This could spur Kenya to rapid industrialization. However, inclusion of teaching staff and students in home-based industrial production was not given due attention.

Unlike the Chinese, Indian youth preferred white-collar jobs to home-based industries and farm based occupations (Agrawal, 2011 and $\mathrm{Wu}, 2011$ ). This situation can be attributed to the emphasis on general education compared as opposed to TIVET instruction. TIVET instructions in India, Bangladesh and the Mongolia was faced with challenges including shortage of instructors, lack of funds and a mismatch between supplied and demanded skills. The intervention strategies adopted by India and Bangladesh involved privatepublic partnership, provision of adequately trained teaching staff and performance based funding as well as competence-based training and assessment facilitated through TIVET-industries partnership (ILO, 2010; Kerre, 2011 and Ngerechi, 2003). Particularly, the industry-TIVET partnership 
aimed at in-company training, provision of training equipments, practical training, and setting up workshops, laboratories and support delivery of modern training materials.

The provision of TIVET instructions in Kenya among other African countries such as Egypt, Nigeria and Tanzania was characterised by instructional related challenges that include shortage of qualified staff, institutional lack of modern equipments and facilities, lack of industrial experience among teaching staff and overemphasis on theoretical and analytical skills with less practical activities for creative innovations (Amuka, Olel \& Gravenir, 2011 and Muthaa, 2009). Student related challenges included high failure and referrals rate leading to mass wastage, lack of prerequisite skills, low morale for study due to the view that TIVET was meant for less academically gifted students, hence reduced internal efficiency (Kerre, 2010; Muthaa, 2009 and Ngerechi, 2003). In particular, Nigerian TIVET had high instructorstudent ratio, obsolete equipment, and low morale among teaching staff. In Kenya and Egypt, lack of training quality and relevance and shortage of modern equipments and facilities had been witnessed while in Kenya and Nigeria there were 
shortage of qualified staff, lack of modern equipments and facilities in institutions, lack of industrial experience among teaching staff and shortage of funding to finance TIVET activities. These challenges undermine competence for creative innovations. Social and industrial partners could play an important role in improving quality and relevance of training; encourage competencebased training and assessment as well as sourcing for funding to meet the logistical and instructional financial needs of TIVET. However, collaborative industrial attachment of teaching staff and students as an intervention strategy for creative innovations had not been given due attention.

The Kenyan government was committed to overcome instructional challenges in an attempt to improve competence in TIVET disciplines. The Kenyan intervention mechanism was TIVET, social and industrial partnership through active and continuous transfer of technology (Kerre, 2010; Ngerechi, 2003 and Muthaa, 2009). Similarly, Nigeria, Egypt, Republic of Ireland, Sweden, Switzerland, Brazil, India, and Mongolia among others sought to work with social and industrial partners such as industrial supervisors, private enterprises, training companies, trade unions and 
employer associations. Their partnership was meant to provide opportunities for students' supervised industrial attachment, competencebased training and assessment, financial support, streamlining TIVET instructional policies and review of curricula and ethic policies (ILO, 2010, Kerre, 2011 and Ngerechi, 2003). The partnership between academic staff and industrial supervisors, employer associations and trade unions sought to develop instructors' retraining packages to establish master trainers, establish opportunities for joint policy formulation and development, experience in work and business processes (Kuppe \& Loring, 2006). In Brazil, the funding was to be nagged by employer organizations. The trade unions were to identify the key competency needs. The enterprises identified training priorities and carried out course curriculum design (ILO, 2010). The teaching staff industrial attachment, if adopted and practised, could offer consultancy services, supervise students during their industrial attachment, provide theoretical courses to the apprentices, conduct research and development to improve industrial processes and develop goods and services that are globally competitive. Although a combination of teaching and students' industrial attachment could improve creative innovations, the 
strategy had not been fully exploited in Africa, including in Kenya, among developing countries. Hence, this study was justified.

\section{Methodology}

A cross-sectional descriptive survey research design was used. Questionnaires were administered to fifty (50) students and twenty three (23) academic staff. A semi-structured interview schedule was used with thirteen (13) industrial supervisors in Kenya. The instruments were used to collect data related to the role of collaborative industrial attachment between teaching staff and students in developing creative and innovative competencies needed for rapid industrialization. The study represented the results in frequency tables showing the frequency and percentages in parentheses on the opinion of students, lecturers and industrial supervisors on the role of supervised industrial attachment. The results were discussed to respond to research objectives and questions. 


\section{Results and Discussions}

The results were analyzed and discussed under the following five study questions.

Question (i): What are the benefits of teaching staff industrial attachment?

Table 1 showed results related to benefits of academic staff industrial attachment

\begin{tabular}{|l|l|l|l|}
\hline Statement & Student & $\begin{array}{l}\text { Lec- } \\
\text { turer }\end{array}$ & Supervisor \\
\hline $\begin{array}{l}\text { Impart relevant and up-to-date } \\
\text { knowledge and skills to effectively } \\
\text { support industries }\end{array}$ & $31(62 \%)$ & $20(86 \%)$ & $11(84.6 \%)$ \\
\hline $\begin{array}{l}\text { Nurture linkage with industry for } \\
\text { students industrial attachment }\end{array}$ & $28(56 \%)$ & $20(86 \%)$ & $10(76.9 \%)$ \\
\hline $\begin{array}{l}\text { Professional do part-time teaching } \\
\text { with apprentices in the industries }\end{array}$ & $29(58 \%)$ & $19(83 \%)$ & $9(69.2 \%)$ \\
\hline $\begin{array}{l}\text { Appropriate explanations and facili- } \\
\text { tate discussion giving latest exam- } \\
\text { ples }\end{array}$ & $33(66 \%)$ & $21(91 \%)$ & $9(69.2 \%)$ \\
\hline $\begin{array}{l}\text { Broaden instructors knowledge and } \\
\text { experience }\end{array}$ & $34(68 \%)$ & $17(74 \%)$ & $12(92.3 \%)$ \\
\hline $\begin{array}{l}\text { Able to provide latest information } \\
\text { about the industry and expected } \\
\text { expertise }\end{array}$ & $30(60 \%)$ & $19(83 \%)$ & $11(84.6 \%)$ \\
\hline $\begin{array}{l}\text { Facilitate organizational stability } \\
\text { and security }\end{array}$ & $33(66 \%)$ & $18(78 \%)$ & $12(92.3 \%)$ \\
\hline $\begin{array}{l}\text { Elaborate theoretical aspects more } \\
\text { effectively and efficiently }\end{array}$ & $31(62 \%)$ & $17(74 \%)$ & $11(84.6 \%)$ \\
\hline $\begin{array}{l}\text { Improve efficiency and effectiveness } \\
\text { in the working culture }\end{array}$ & $34(68 \%)$ & $20(86 \%)$ & $12(92.3 \%)$ \\
\hline $\begin{array}{l}\text { Inculcate values and develop well } \\
\text { balanced students in spiritual and } \\
\text { academic achievement }\end{array}$ & $28(56 \%)$ & $14(61 \%)$ & $10(76.9 \%)$ \\
\hline
\end{tabular}




\begin{tabular}{|l|l|l|l|}
\hline $\begin{array}{l}\text { Improve confidence in sharing knowledge } \\
\text { and skills with colleagues and students }\end{array}$ & $\begin{array}{l}49 \\
(98 \%)\end{array}$ & $\begin{array}{l}20 \\
(86 \%)\end{array}$ & $\begin{array}{l}11 \\
(84.6 \%)\end{array}$ \\
\hline $\begin{array}{l}\text { Use specialized equipment, machinery and } \\
\text { tools not available at college }\end{array}$ & $33(66 \%)$ & $\begin{array}{l}19 \\
(83 \%)\end{array}$ & $\begin{array}{l}12 \\
(92.3 \%)\end{array}$ \\
\hline $\begin{array}{l}\text { Expose students to challenges faced in the } \\
\text { outside world situations }\end{array}$ & $\begin{array}{l}32 \\
(64 \%)\end{array}$ & $\begin{array}{l}17 \\
(74 \%)\end{array}$ & $\begin{array}{l}10 \\
(76.9 \%)\end{array}$ \\
\hline $\begin{array}{l}\text { Acquaintance with new technologies, } \\
\text { machines and equipment function }\end{array}$ & $\begin{array}{l}30 \\
(60 \%)\end{array}$ & $\begin{array}{l}17 \\
(74 \%)\end{array}$ & $\begin{array}{l}11 \\
(84.6 \%)\end{array}$ \\
\hline $\begin{array}{l}\text { Bridge the gap between higher learning } \\
\text { and industry requirements in terms of } \\
\text { skills }\end{array}$ & $25(50 \%)$ & $\begin{array}{l}19 \\
(83 \%)\end{array}$ & $\begin{array}{l}12 \\
(92.3 \%)\end{array}$ \\
\hline $\begin{array}{l}\text { Use hand-outs provided during industrial } \\
\text { attachment for instructions }\end{array}$ & $25(50 \%)$ & $21(91 \%)$ & $\begin{array}{l}11 \\
(84.6 \%)\end{array}$ \\
\hline
\end{tabular}

The current study, the work by Kerre (2011) and Kerre (2010) concurred that industrial attachment could meet the experiential training needs of Kenyan TIVET instructors. Similarly, the current study, ILO (2010), Kerre (2011), and Obonyo (2011) agreed that developed countries like the UK and US; developing and transitional countries like Kenya, Singapore, Egypt, India, China and Ghana need to re-orient their TIVET educators training and embrace continuous development to meet the challenge of modern, changing and emerging technologies. The agreed intervention could spur Kenyan manpower into creative innovations necessary to tap into the greening economy, obtain the scientific and technological human and material resources 
needed for use of renewable energy; reduce carbon emissions; introduce environmental friendly industrial systems and be globally competitive.

Question (ii): What activities can be carried out by teaching staff industrial attachment for competence development?

Table 2 was used to show activities that teaching staff could undertake in their industrial attachment to develop competence in creative innovations.

\begin{tabular}{|l|l|l|}
\hline Statement & Lecturer & Supervisor \\
\hline $\begin{array}{l}\text { Carry out industry-related funded research } \\
\text { activities to finance TIVET }\end{array}$ & $19(83 \%$ & $11(84 \%)$ \\
\hline $\begin{array}{l}\text { Customer oriented product design and packag- } \\
\text { ing activities }\end{array}$ & $21(91 \%)$ & $13(100 \%)$ \\
\hline $\begin{array}{l}\text { Use specialized equipment, machinery and tools } \\
\text { not available at college }\end{array}$ & $17(74 \%)$ & $12(92 \%)$ \\
\hline $\begin{array}{l}\text { Support consultation services to bridge gap } \\
\text { between theory and practice }\end{array}$ & $18(78 \%)$ & $12(92 \%)$ \\
\hline $\begin{array}{l}\text { Collection, analysis, presentation, interpretation } \\
\text { of data for decision making }\end{array}$ & $20(86 \%)$ & $13(100 \%)$ \\
\hline $\begin{array}{l}\text { Form part of think tank for innovation and prob- } \\
\text { lem solving }\end{array}$ & $20(87 \%)$ & $12(92 \%)$ \\
\hline $\begin{array}{l}\text { Sharpen and Apply manipulative skills using } \\
\text { hand-held tools and equipments }\end{array}$ & $20(87 \%)$ & $13(100 \%)$ \\
\hline $\begin{array}{l}\text { Work with industrial supervisors in developing } \\
\text { manuals for industrial attachment and assess- } \\
\text { ment besides being a co-supervisory and trainer }\end{array}$ & $19(83 \%)$ & $12(92 \%)$ \\
\hline $\begin{array}{l}\text { Acquaintance with how new technologies, ma- } \\
\text { chines and equipment function }\end{array}$ & $16(70 \%)$ & $9(69 \%)$ \\
\hline $\begin{array}{l}\text { Participate in brain-storming sessions for prob- } \\
\text { lem solving }\end{array}$ & $20(86 \%)$ & $12(92 \%)$ \\
\hline
\end{tabular}


The current study, the work by Brown (2003), Duger (2011), ILO (2010), Kerre (2010), Kuppe \& Loring (2006) and Yan (2011) concurred that partnership between academic staff, industrial supervisors, employer associations and trade unions could develop instructors' retraining packages to establish master trainers, establish opportunities for joint policy formulation and development, experience in work and business processes. The partnership between TIVET teaching staff and industries in Kenya among other countries such as Brazil was meant to provide opportunities for students' supervised industrial attachment, competence-based training and assessment, financial support, streamlining TIVET instructional policies, and industrial attachment for students, review of curricula and ethic policies and ensure that funding was managed by employer organisations. The current study and the work by Duger (2011), Kuppe \& Loring (2006) and Yan (2011) concurred that trade unions could identify key competency needs. The current study and the work by Duger agreed that Kenyan and Australian TIVET staff and industries could adopt market-based pricing to meet demanded training needs through benchmarking where clients negotiated and purchased needed training. 
Question (iii): What competence in soft skills is developed by teaching staff and their students through industrial attachment?

The results in Table 3 showed the competence in soft skills developed among teaching staff and their students through industrial attachment

\begin{tabular}{|l|l|l|l|}
\hline $\begin{array}{l}\text { Competence in soft skills } \\
\text { developed include: }\end{array}$ & Student & lecturer & Supervisor \\
\hline $\begin{array}{l}\text { Critical and creative thinking } \\
\text { skills }\end{array}$ & $33(66 \%)$ & $18(78 \%)$ & $11(84 \%)$ \\
\hline Problem-solving skills & $30(60 \%)$ & $17(74 \%)$ & $11(84 \%)$ \\
\hline Negotiation skills & $31(62 \%)$ & $16(70 \%)$ & $10(77 \%)$ \\
\hline $\begin{array}{l}\text { Information handling skills for } \\
\text { effective communication }\end{array}$ & $29(58 \%)$ & $17(74 \%)$ & $12(92 \%)$ \\
\hline Conflict resolution skills & $33(66 \%)$ & $17(74 \%)$ & $10(77 \%)$ \\
\hline $\begin{array}{l}\text { Assertiveness without being } \\
\text { offensive }\end{array}$ & $30(60 \%)$ & $18(78 \%)$ & $12(92 \%)$ \\
\hline Team-work skills & $35(70 \%)$ & $17(74 \%)$ & $10(77 \%)$ \\
\hline $\begin{array}{l}\text { Ability to engage in community } \\
\text { service }\end{array}$ & $33(66 \%)$ & $17(74 \%)$ & $12(92 \%)$ \\
\hline Physical and mental wellbeing & $25(50 \%)$ & $16(70 \%)$ & $10(77 \%)$ \\
\hline Coping with stress & $33(66 \%)$ & $17(74 \%)$ & $10(76.9) \%$ \\
\hline $\begin{array}{l}\text { Healthy interpersonal relation- } \\
\text { ships and (psychological health) }\end{array}$ & $34(68 \%)$ & $21(91 \%)$ & $12(92.3 \%)$ \\
\hline $\begin{array}{l}\text { Make informed and effective } \\
\text { decisions (informed choices) }\end{array}$ & $34(68 \%)$ & $18(78 \%)$ & $10(76.9 \%)$ \\
\hline $\begin{array}{l}\text { Translate knowledge, attitudes, } \\
\text { skills and values into action }\end{array}$ & $22(44 \%)$ & $17(74 \%)$ & $11(84.6 \%)$ \\
\hline
\end{tabular}


Results from the current study, findings by Ahmad and Rashid (2011) on the need for manpower development in skills for global stability and security, the study by Kairu (2012) on Kenya's need to develop skills necessary for practical work ethics, the work by Mudashir (2011) on newly employed TIVET instructors' lack of industrial skills in Nigeria as well as the research by Kuppe and Loring (2006) and Norbech (2002) on the role of social and industrial partners in developing a suitable environment for enduring and sustainable creative innovations in engineering education in UK concurred on the need for collaboration of teaching staff and students industrial attachment for training and development in soft skills. The current study and reviewed literature identified the need for development of manpower with competence in soft skills for sustainable creative innovations for rapid industrialization desired in Kenya. 
Question (iv): What challenges do students face during industrial attachment?

The results in Table 4 show the challenges faced by students during industrial attachment.

Table 4: Challenges faced by teaching staff and students during industrial attachment

\begin{tabular}{|l|l|l|l|}
\hline Challenges & Student & Lecturer & $\begin{array}{l}\text { Superviso } \\
\mathbf{r}\end{array}$ \\
\hline $\begin{array}{l}\text { Language barriers in multi- } \\
\text { national organisations }\end{array}$ & $35(70 \%)$ & $\begin{array}{l}20 \\
(86.9 \%)\end{array}$ & $12(92.3 \%)$ \\
\hline $\begin{array}{l}\text { Some industrial mentors } \\
\text { lack the ability to seek for } \\
\text { knowledge and information }\end{array}$ & $49(98 \%)$ & $\begin{array}{l}18 \\
(78.2 \%)\end{array}$ & $11(84.6 \%)$ \\
\hline $\begin{array}{l}\text { Inadequacy of knowledge } \\
\text { and skills in college to deal } \\
\text { with current industrial } \\
\text { needs }\end{array}$ & $33(66 \%)$ & $\begin{array}{l}19 \\
(82.6 \%)\end{array}$ & $11(84.65)$ \\
\hline $\begin{array}{l}\text { Some mentors inflexibility } \\
\text { in accommodating } \\
\text { alternative conception of } \\
\text { the problem }\end{array}$ & $34(68 \%)$ & $\begin{array}{l}17 \\
(73.9 \%)\end{array}$ & $12(92.3 \%)$ \\
\hline $\begin{array}{l}\text { Few ladies to mentor and } \\
\text { encourage their female } \\
\text { apprentices in the } \\
\text { profession }\end{array}$ & $33(66 \%)$ & $\begin{array}{l}17 \\
(73.9 \%)\end{array}$ & $9(69.2 \%)$ \\
\hline
\end{tabular}

The current study concurred with Agrawal (2011) and IICBA (2012) that the challenges experienced during industrial attachment revolve around little or no support from social and 
industrial partners. That was because industrial attachment trainees sometimes have little or no follow-up (Agrawal, 2011 and IICBA, 2012). The results in the current study concurred with the objective of Kenyan TIVET in Kerre (2010), Ngerechi (2003) and Muthaa (2009) on the need to have active and continuous transfer of technology through collaborative approaches between TIVET institutions and the relevant industries. The current study concurred with Kuppe and Loring (2006) that although challenges were experienced during the involvement of industrial and social partners such as industrial supervisors, employer associations and trade unions could develop instructors' retraining packages to establish master trainers, establish opportunities for joint policy formulation and development, experience in work and business processes. The funding was to be managed by employer organizations. The trade unions could be involved in identifying the key competency needs. The current study and that by Kerre (2010), Ngerechi (2003) and Muthaa (2009) concurred that social and industrial partners working with teaching staff in their industrial attachment could develop sound policy, provide accreditation and certify competence-based training and assessment (CBTA). The current study 
concurred with Agrawal (2011) and IICBA (2012) on the need to seek for social and industrial partners such as industrial supervisors, private enterprises training companies, trade unions and employer associations in manpower development for creative innovations. However, the role that could be carried out by teaching staff in industrial attachment to reduce or eliminate the above mentioned limitations was not fully addressed. The industrial attachment of teaching staff could provide a link between TIVET institutions and social as well as industrial partners. The attachment, if adopted and practised, could work toward offering consultancy services, supervise students during industrial attachment, provide theoretical courses to the apprentices, conduct research and development to improve industrial processes and develop goods and services that are globally competitive. Although integration of teaching and students industrial attachment could improve creative innovations, the strategy had not been fully exploited in Africa, at least not in Kenya. Hence, this study was justified. 


\section{Conclusion and Recommendations}

Results of the current study indicated that supervised industrial attachment plays an important role in establishing a link with industrial and socio-partners, relating teaching and learning processes to the latest development in industries, and provides opportunities of working with most current technology, machinery, equipment, tools and systems. Further, it contributes to creative innovations in product and industrial processes, involves the industrial staff in students' competence development, reduces the cost of recruitment and hence improves industrial savings. The study concluded that if academic staff and students go for industrial attachment at the same time, collaborative teaching and learning would occur simultaneously and this would improve students' competence, spur creative innovations, support and encourage quality and globally competitive industrial output. The study recommends the involvement of industrial and social partners in policy formulation, design, implementation, financing and standardised assessment of collaborative supervised industrial attachment for students and academic staff. 


\section{References}

Agrawal, V. K. (2011, December13). Preparing TVET educators for next generation of India. Paper presented at the EDUCON 2011 conference in Preparing TVET educators for the next generation (EDUCON), Kuala Lumpur: Centre for Technical Vocational Training.

Ahamad, M. F. B. and Rashid, K. A. A. (2011).

Lecturers industrial attachment programme to increase lecturers soft skills and technological competencies for global stability and security. Journal of Sustainable Development, 4 (1): 281-283.

Amuka, L. M., Olel, M. A. and Gravenir, F. (2011). Examination of the effect of cost sharing on science and technology education and training in Kenya National Polytechnics. Australian Journal of Business and Management Research, 1 (2)

Brown, B. L. (2003). International models of career-technical education. Education resources information centre (ERIC). Clearing House on adult, career and vocational education. [Electronic version]. 
Library media connection, Trends and Issues alert no. 42.

Brunette, H. C. (2006). Technical education in Namibia: Past trends, present circumstances and future prospects. Published doctoral thesis. Windhoek: University of Free Town.

Duger, B. (2011). Good practices and emerging challenges. Preparing TVETE educators for the next generation Conference (EDUCON, 2011), Conference Report, December, 12-13, 2011, UNESCOUNEVOC, Kuala Lumpur: Centre for Technical Vocational Training.

Gatonye, G. and Mathenge, O. (2009, July 23). Good morning teacher robot: Japan may soon roll out first human-like tutors to take over classrooms. Daily Nation, p. 3.

Government of Kenya (GoK). Ministry of Higher Education Science and Technology (MoHEST). (2010). Handbook for accreditation of TIVET institutions. Nairobi: Directorate of Technical Accreditation, Quality and Assurance. 
GoK (2009). The Kenya National Examination

Council (KNEC) (2006 - 2008), Results

analysis. Diploma Technical Education Programme. (Mechanical and Automotive Engineering, and Mechanical Technology). Nairobi: KNEC.

GoK, MoHEST. (2005). Strategic Plan 2007-2012. Nairobi: Government Press.

International Institute for Capacity Building in Africa (IICBA) (2012). The role of teacher training in technical and vocational education and training (TVET) in Africa. Paris: IICBA. [Electronic version]. Library media connection, 13(2): 1-20.

International Labor Organization (ILO). (2010, September 29-30). Teachers and trainers for future- technical and vocational education and training: Report for discussion at global dialogue forum on vocational education and training. ILO-Sectoral Activities programmes. [Electronic version]. Library media connection. 
Kairu, P. (2012, February 19th). Kenya: Lecturers to get a feel of industries before training others. Daily Nation. Retrieved on November 23rd 2012from http://www.nation.co.ke

Khakala, M.M.O (2009). Proficiency in pedagogical content knowledge in mathematics: secondary school mathematics teachers' interpretation of students' solving strategies in Kenya. Unpublished doctoral thesis, Kenyatta University, Nairobi, Kenya.

Kerre, B.W. (2011). TVET Education for Green society and Economy: The development of TVET educators in Africa, Good practices and emerging challenges. Paper presented at the EDUCON, 2011 conference in Preparing TVET educators for the next generation (EDUCON), Corus Kuala Lumpur, Malaysia. Centre for Technical Vocational Training.

Kerre, B.W. (2010, March 25 $\left.{ }^{\text {th }}\right)$. Technical and Vocational Education and Training (TVET): A Strategy for National Sustainable Development. Inaugural Lecture 9 Series No. 1, 2010. Eldoret: Moi University Press. 
King, K. and Palmer, R. (2010). Planning for technical and vocational skills development: fundamentals of educational planning. Paris: International Institute for Educational Planning (IICBA). Retrieved on October, $16^{\text {th }} 2012$ from http:// www.iiep.unesco.org

Kuppe, A.M. \& Loring, B. (2006, December 13). Vocational Training and Regulation and the Process Behind Them. Bonn: Federal Institute for Vocational Education and Training.

Maclean, R. (2007). Vocational and higher education issues, concerns and prospects. Bonn: International Centre for Technical and Vocational Education and Training.

Maithya, R. and Ndebu, S. (2011, July 22nd). Factors influencing effective use of ICT in teacher education: A Case of Kenya Technical Teachers College. Quality Education for Societal Transformation. International Conference on Education, Kenyatta University Conference Centre, Nairobi.

Mar, N.Y. (2011). Re-orienting TVET towards sustainable development: The role of teacher 
professionals and the UNEVOC Network.

Paper presented at the EDUCON, 2011

conference in Preparing TVET educators for the next generation (EDUCON), Corus Kuala Lumpur, Malaysia. Centre for Technical Vocational Training.

Mudashir, I. (2011, December 12th). Nigeria:

Polytechnic lecturers to undergo industrial attachment. Kaduma, Daily Trust.

[Electronic version]. Library media connection.

Muthaa, G. M. (2009). Relevance of skills offered by technical training institutes to employment needs in industries and business organizations in Kenya. Unpublished Doctoral Thesis. Chuka University College. Chuka, Kenya.

Muthoni, D.M. (2012). Improving Achievement in Mathematics through Collaborative Learning. Nairobi: Lambert.

National Council of Science and Technology (NCST) (2012, June). The World of science, technology and innovation. A newsletter of NCST, Kenya, issue 18. 
Ngerechi, J. B. (2003, August 4). Technical and Vocational Education and Training in Kenya. A paper presented at Conference on the Reform of Technical Regulatory Instruments for Quality Assurance of TVET and Vocational Education and Training (TVET), Gaborone, Botswana.

Ngware, M. W. (2000). Internal efficiency and its relationship to equity in institutes of technology in Kenya. Unpublished PhD Thesis. Egerton University, Nakuru, Kenya.

Norbech, P.I. (2002, August 21). Partnership for creative engineering education. Manchester, UK. International conference on engineering education.

Nyantino, J. (2009, June 2). 'Use mobile phones as teaching aids,'Nairobi, Daily Nation, p. 11.

Obonyo, E. A. (2011, July 22). Developing Global Scientists and Engineers: Engineering Sustainable Building Systems in Quality Education for Societal Transformation, Paper presented at the International Conference on Education, Kenyatta University Conference Centre, Nairobi. 